\title{
Chemical Studies on Impact of Air Pollution on Wheat Crops of Vindhya Region of Madhya Pradesh, India
}

\author{
Dr. Vinod Kumar Dubey ${ }^{1 *}$, Aparna Pandey ${ }^{2}$, Archana Shukla ${ }^{3}$
}

\begin{abstract}
For most of the people specially belong to the Northern India, wheat is a very important crop because their main fooding depend upon wheat, there are several eatable food products prepared by wheat. Wheat is cultivated mostly in Punjab, Haryana, Uttar Pradesh, Bihar, West Bengal and Madhya Pradesh. Recently in these states industrialization and infrastructural development work are going very fast causing huge amounts of pollutants and particulates entering into the atmosphere. Pollutants are mainly oxide of carbon, oxide of nitrogen, oxide of sulphur, oxide of chlorine, chloride ions, ammonia, organic acids and aldehydes where as particulates are dust, smoke, mist and fog particulates are deposited on the surface of wheat some of these particulates are hydroscopic in nature. They absorb pollutants and form acids. These acids in turn develop micro electrochemical call with flower of wheat which destroy flowering of wheat. Other factors are acid rain; global warming and depletion of ozone layer also affect the production of wheat crops.
\end{abstract}

Keywords : Pollutant, Particulates, Electrochemical cell, Wheat flower, Acid Rain, Ozone depletion and Global warming.

\section{Introduction:}

The Vindhya Region of Eastern Madhya Pradesh includes district Sidhi, Rewa Rewa, Stana and Shohdol. The larger area of this region known as "Ganga Basin" where several rivers like Son, Gopad, Banash, Bichhiya, Beehar and Tones are contributing substantially towards cultivation of wheat to meet the demand of people of this region at large.

Presently these areas are flooding with industries, like chemical, coal, fertilizer, cement, food processing. Paper and pulp, transport, thermal power generation, hydrolytic power generation, drug, paint and dyes, sugar industry, wine industry, water boiling plants, juice factory, milk processing etc.

These industries release hung amount of pollutants, like inorganic, organic, and particulates material. They pollute air and that polluted air produces several problems for living and non-living things.

Inorganic pollutants are oxides of carbon such as $\mathrm{Co}, \mathrm{CO}_{2}$, oxides of nitrogen such as $\mathrm{No}, \mathrm{N}_{2} \mathrm{O}, \mathrm{NO}_{2}$, oxides of sulphar such as $\mathrm{SO}_{2}, \mathrm{SO}_{3}$ oxides of chlorine, chloride ion, ammonia and oxides of metals. Organic pollutants are organic acids, aldehydes, ketones, aminos etc. particulates are dust, smoke, mist, pollen, bacteria and fog.

Wheat flowering period starts from December to February. Particulates are scattered into the atmosphere which are deposited on the surface of wheat crop. Some of these particulates are hydroscopic in nature. The absorb moisture from the atmosphere. The moist particulate absorb oxides of carbon, oxides of nitrogen, oxides of sulphare, oxide of chorine, and chlorine ion to form carbonic acid, nitric acid, sulphuric acids, hypochlorus acid and hydrochloric acid. These acids are highly corrosive in nature, they create hostile environment for wheat flowers. The corrosive acids produces micro-electrochemical cell with wheat flowers. Thus electrochemical reaction occurs on the surface of wheat flowers in this way flower of wheat get destroyed and conversion of flowers into wheat is decreased.

\section{Methodology :}

For this work certain wheat growing areas were selected in district Singrauli, Shahdol, Satna, Rewa and Sidhi of Vindhya Region of eastern M.P. The study of the characteristic behaviors of inorganic, organic and particulates pollutants and their effect on wheat flowers were done in details monitoring works started during period of December to February (2012-13) corrosive gases and their acidic character were determined with the help of PH meter.

*1 Professor, Applied Chemistry Division, Deptt. of Chemistry, SGS Govt. P.G. Autonomous (NAAC Accredited) College, SIDHI486661 (M.P.) India

2. Assistant Professor and Head of Dept. of Chemistry, Kamla Memorial College, Padara, SIDHI 486661 (M.P.) India

3. Research Scholar at Applied Chemistry Division, Deptt. Of Chemistry, SGS Govt. P.G. Autonomous (NAAC Accredited) College, SIDHI-486661 (M.P.) India 
Table 1 : PH values of corrosive Pollutants in studied area

\begin{tabular}{|l|c|}
\hline Studied Area & PH Value \\
\hline Rewa & 5.9 \\
\hline Satna & 6.5 \\
\hline Shahdol & 5.5 \\
\hline Singrauli & 6.7 \\
\hline Sidhi & 5.01 \\
\hline
\end{tabular}

\section{Result and Discussion :}

Wheat is main food of human being and apart from nature; man creates its own environments. Due to infrastructural development in several sectors like, industry, agriculture, power generation cement industry construction work etc. the environment of the area surrounding these sectors are being pullulated.

The main features of wheat depend upon temperature, humidity and nature of surrounding environment during its flowering period. The concentration of corrosive gages, particulate materials and humidity are high so they form $\mathrm{H}_{2} \mathrm{CO}_{3}, \mathrm{H}_{2} \mathrm{SO}_{4}, \mathrm{HNO}_{3}, \mathrm{HClO}$ and $\mathrm{HCl}$. These acids produce $\mathrm{H}^{+}$ion that ion starts electrochemical reaction with wheat flower. Due to this reaction flowers connectivity becomes weaker and finally they are detached with main branch of wheat plant. During the formation of acids exothermic reaction occurs and heat is evolved which increases the temperature of surrounding of wheat flowers thus flowers are easily separated from its main branch.

The chemical reactions among them are as follows -

$$
\begin{aligned}
& \mathrm{CO}_{2}+\mathrm{H}_{2} \mathrm{O} \\
& \mathrm{No}+\mathrm{O}_{2} \\
& \mathrm{No}_{2}+\mathrm{H}_{2} \mathrm{O} \\
& \mathrm{SO}_{2}+\mathrm{O}_{2} \\
& \mathrm{SO}_{3}+\mathrm{H}_{2} \mathrm{O} \\
& \mathrm{Cl}^{-}+\mathrm{H}_{2} \mathrm{O}
\end{aligned}
$$

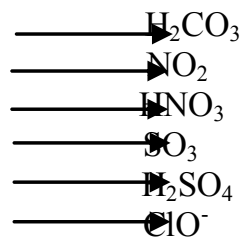

The above produced acids are dissociated and released $\mathrm{H}^{+}$ion that ions in the presence of electrolyte develop an electrochemical cell causing oxidation and reduction reactions to start on the surface of wheat flowers. The electrochemical reaction is expressed as-

$$
\begin{aligned}
& \text { Half oxidation reaction - } \\
& \mathrm{CH}_{2} \mathrm{O} \longrightarrow \mathrm{CO}_{2}+2 \mathrm{H}^{+}+2 \mathrm{e} \\
& \text { Half reduction reaction - } \\
& 2 \mathrm{H}^{+}+2 \mathrm{e}
\end{aligned}
$$

The Chemical reaction indicates that corrosive pollutants are corroding the wheat flowers. The $\mathrm{PH}$ values of above mentioned studied area recorded in table 1 and bar graph plots between the PH values of corrosive pollutants and its concentration and with different studied are in fig. 1

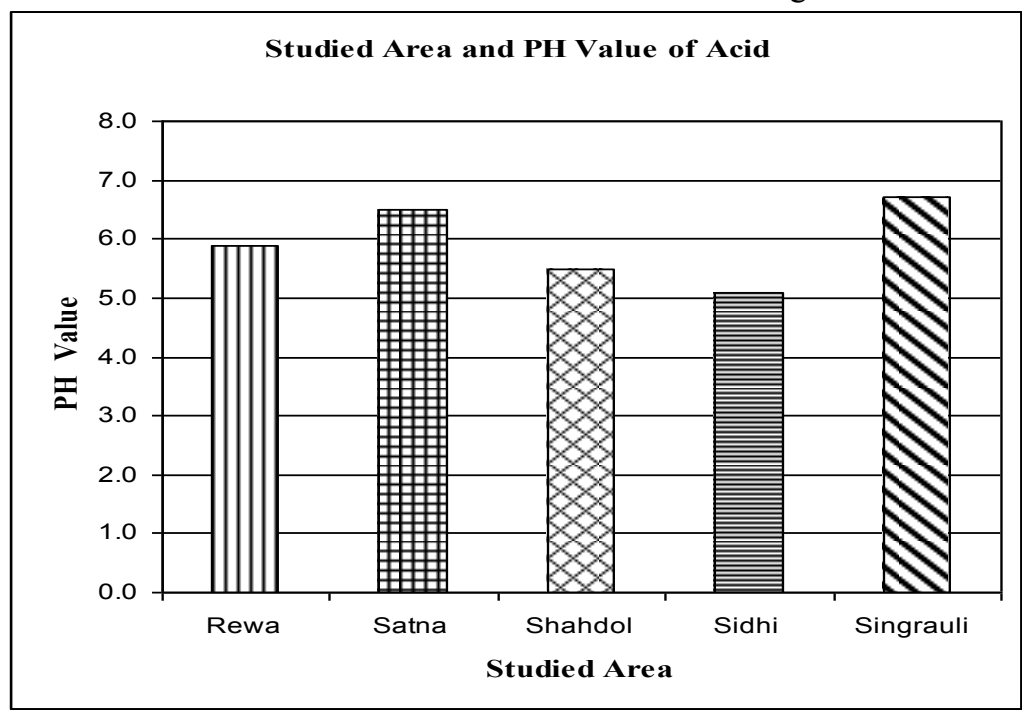

Fig. 1 Plot between studied area and PH value of acids

The result of table 1 and fig. 1 shows that the concentration of $\mathrm{H}^{+}$ion in Shahdol is higher than that of Satna and Rewa likewise the concentration of $\mathrm{H}^{+}$ion in Satna is greater than Singrouli and Wheat crops of these areas are badly affected by pollutants. 
The concentration of $\mathrm{CO}_{2}$ and methane gases increases in atmosphere due to deforestation, industrialization and human waste decomposition. These gases produce global warming effect thus temperature of atmosphere is increased which exhibit bad affect on the wheat flowers. In lower level of atmosphere ozone is formed that ozone also disturbs wheat flowers.

$$
\begin{array}{lll}
\mathrm{O}_{2} & +\mathrm{Uv} & \mathrm{SO}_{2} \mathrm{SO}_{4} \\
\mathrm{O}_{2} & +\mathrm{O} & \mathrm{P}_{3} \text { (ozone) }
\end{array}
$$

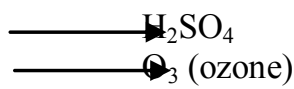

\section{Conclusion :}

Pollutants are very harmful for wheat Flowers, they decrease its production. If its evolvement is not controlled at proper times our country will become major loser of wheat crops. It is moral responsibility of the industrialist, scientists, Intellectuals, social workers to provide good technology and public awareness against pollution.

\section{Reference:}

[1]. "Green Engineering"- environmentally conscious Design of Chemical Processes by David T. Allen and David R. Shonnart. Prentice Hall (2003)

[2]. "Environmental Chemistry" By S. E. Manahan, Willard Grant Press, Boston (1983)

[3]. "Air Pollution" By A. C. Stern, Academic Press, New York (1976)

[4]. "Pathways of Pollutants in the atmosphere" by T. M. Sugden (Ed), The Royal Society London (1978)

[5]. Hand Book of Pollution control and waste minimization edited by Abbas Ghassemi Marcel Dekker inc (2002)

[6]. B. J. Pitts, Atmosphere Chemistry, Academic Press, Wiley N.Y. (1986)

[7]. Environment - Problems and Solutions By D. K. Asthana and Meera Asthana, S. Chand \& Co. Ltd. New Delhi (1998)

[8]. "Environmental chemistry" By Nigel J. Bunce, Wuerz Publishing Ltd. Canada (1991)

[9]. "Introduction to Environmental Engineering and Science" By G. M. Masters, Prentice Hall, New Delhi (1994)

[10]. "Fundamentals of Air Polution" By J. Williamson, Addison- Wasley, Reading Mass (1973)

[11]. R. P. Wayne the Chemistry of the Atmosphere, Oxfored Univeristy Press N. Y. (1991)

[12]. "Air Pollution" By H. C. Perkins, McGraw Hill, New York (1974) 